Bond University ePublications@bond

Sports Law eJournal

Faculty of Law

9-1-2012

\title{
The obligations of mutual fidelity between athletes and their employers
}

David Thorpe

University of Technology, Sydney

Follow this and additional works at: http://epublications.bond.edu.au/slej

Part of the Law Commons

\section{Recommended Citation}

David Thorpe. (2012) "The obligations of mutual fidelity between athletes and their employers" Sports Law eJournal, 22, 1-9: ISSN 1836-1129.

http://epublications.bond.edu.au/slej/14 


\title{
The obligations of mutual fidelity between athletes and their employers
}

\begin{abstract}
This article considers the mutual obligations of fidelity between sportspeople and their employers. Is it an implied obligation of an employee athlete not to compete against his or her employer sporting organisation? Do employee athletes owe a lesser duty of fidelity because their employers routinely display less fidelity themselves?
\end{abstract}

\section{Keywords}

obligations, mutual fidelity, athletes, employers

\section{Disciplines}

Law 


\title{
THE OBLIGATIONS OF MUTUAL FIDELITY BETWEEN ATHLETES AND THEIR EMPLOYERS
}

\author{
DAVID THORPE ${ }^{1}$
}

This article considers the mutual obligations of fidelity between sportspeople and their employers. Is it an implied obligation of an employee athlete not to compete against his or her employer sporting organisation? Do employee athletes owe a lesser duty of fidelity because their employers routinely display less fidelity themselves?

\section{Introduction}

In the age of sporting entrepreneurialism, the staging of a major tournament no longer requires the resources of a sporting monolith. A sports promoter, operating outside the main stream, can hold 'one-off' events or periodic competitions, between rounds, during the offseason or even midweek and, when doing so, draw upon the services of athletes employed by the major sporting organisations. Indeed, as unfair as it seems, the lower costs associated with utilising the sporting talent of the 'establishment' pool serves to improve the financial viability of these alternate tournaments.

Although a main stream sport is unable to prevent the intrusion of a fringe entrepreneur into its realm, and bearing in mind that a ban on secondary employment is a prima facie restraint of trade, ${ }^{2}$ does the employee's implied obligation of fidelity offer an alternate solution to the aggrieved sporting organisation? For example, what is the legal position, say, should an athlete leave the field on a Saturday afternoon and play in a different competition on a Monday evening? What of an employee cricketer who plays mid-week in a breakaway competition, or a rugby player who enters a professional boxing tournament? ${ }^{3}$ What of rugby players who devote part of their season to foreign competition in Europe or Japan before joining their provincial or national team? What of so called 'rebel tours'?4

\footnotetext{
${ }^{1}$ Faculty of Law, University of Technology Sydney.

2 Nordenfelt $v$ Maxim Nordenfelt Guns \& Ammunition [1894] AC 535, 565 per Lord Macnaghten.

${ }^{3}$ In February 2012, rugby player Sonny Bill Williams secured the New Zealand heavy weight boxing championship after defeating Clarence Tillman in a bout that took place during the 'Super Rugby' trials. Although apparently not an employee, consider the illustration of England cricketer Kevin Pietersen who expressed a desire to avoid the English cricket season: 'The controversial South African-born batsman had asked for time off to play the full Indian Premier League season ...': Lalor P, The Australian, 8 August 2012.

${ }^{4}$ As far back as 1985 cricketer Kim Hughes toured apartheid South Africa infringing the rules of the Australian Cricket Board: see Hughes v Western Australian Cricket Association (1986) 69 ALR 660. In 1996, 'Super League' was formed to provide sporting content for Fox Television striking against the tradition of the Australian Rugby League. An alternate competition organised by the World Rugby Corporation challenged the supremacy of the Australian Rugby Union in 1995. Although these types of competition are more likely to involve players in a
} 
This article considers the mutual obligations of fidelity as between an employee and employer in the context of sport. Focus is placed on the implied obligation of an employee athlete not to compete against his or her employer sporting organisation. ${ }^{5}$ There are three broad areas of interest: first, can the obligation of fidelity be invoked as a means to prevent athletes from competing against their employer organisation and second, as a corollary, would non-employer sporting organisations be advantaged by engaging their athletes through a contact of employment. Third, whether sport is relevantly 'different' to other forms of employment such that the standard of fidelity expected of 'ordinary' employees is not apt in respect to athlete employees.

Employee athletes are routinely banned from engaging in secondary income-earning activities outside the sport of their usual employment; even during their spare time. Prevention is often justified as a sensible step in avoiding injury and physical burnout to an athlete whose services have been bought for a not inconsiderable sum. From a sporting organisation's perspective, a ban on secondary employment is also a means of curtailing competition from rival sporting organisations or a method to secure a monopoly in the product endorsement market. For an employee athlete the prevention of secondary employment represents considerable income forgone and the temptation to bring an action in restraint of trade.

Moreover, the obligation 'not to compete', unlike enforcing a restraint of trade, does not require incorporation through an express contractual term. Having said this, given that fidelity is a mutual obligation as between employer and employee, when viewed alongside the peculiarities of the sports employment relationship, the entitlement to curtail secondary employment of athlete is not as clear cut as might be first thought.

\section{The uncertain scope of the employee's obligation of fidelity}

There is no principle of law that prevents an employee from engaging in secondary employment - that is, working for an employer other than his or her primary employer. Nevertheless, as a general proposition an employee must not when 'moonlighting' ${ }^{6}$ harm the business concerns of his or her primary employer or compete with that employer. ${ }^{7}$ To do so is to breach the implied contractual obligations of fidelity and good faith. ${ }^{8}$

The scope of the implied duty of fidelity is a matter of fact and is not defined. ${ }^{9}$ Consideration of the matter is hampered by a doctrinal incoherency and the consequential absence of a

\footnotetext{
compete abandonment of their present employer, the relevance to employee fidelity lies in the possibility of single competitions organised as part-time work for players in established leagues.

5 The obligation of employee fidelity includes the duty not to disclose confidential information, not to accept secret bribes and commissions, and not to make unauthorised comments regarding the employer's business.

6 'Moonlighting', a term used in Capital Aircraft Services Pty Ltd v Nicholas Carl Brolin [2007] ACTCA 8.

${ }^{7}$ Blyth Chemicals v Bushnell (1933) 49 CLR 61 (Blyth Chemicals).

${ }^{8}$ Robb v Green [1895] 2 QB 315, 317.

${ }^{9}$ Hivac Ltd v Park Royal Scientific Instruments Ltd [1946] Ch 169, 174.
} 
clear principle: 'It has been said on many occasions that an employee has a duty of fidelity to his employer.... The practical difficulty in any given case is to find exactly how far that rather vague duty of fidelity extends. ${ }^{10}$ Or, as Lord Denning MR said in Woods v WM Car Services (Peterborough): 'The circumstances are so infinitely various that there can be, and is, no rule of law saying what circumstances justify and what do not' ${ }^{11}$

The question of present concern is at what point or through what circumstances can the implied duty of fidelity be used by a sporting organisation to prevent the athlete employee from engaging in secondary income-earning activities during his or her free-time. ${ }^{12}$ From the employee's perspective, the use of his or her spare time to earn additional income is a personal choice not lightly to be surrendered. Limiting spare time earnings also involves important questions of policy which inevitably come to bear on the judicial view as to the correct scope of the obligation.

The employee's obligation not to compete with the employer was considered in Australia in Blyth Chemicals $v$ Bushnell. ${ }^{13}$ The employee, Bushnell, an industrial chemist, established on his own behalf a firm called Electrolytic Lead Products and appointed himself chairman of directors for life. This new company manufactured white lead for use in paints. Bushnell's primary employer, Blyth Chemicals, manufactured chemicals, many of which were lead based, for use on fruit trees. Blyth Chemicals believed that with a little effort Bushnell could convert his equipment to produce chemicals similar to its own and capture Blyth's customers. In anticipation of this, Blyth Chemicals sacked Bushnell. The High Court found the employee had been wrongfully dismissed, Dixon and McTiernan JJ stating:

the conduct of the employee must of itself involve the incompatibility, conflict, or impediment, or be destructive of confidence. An actual repugnance between his acts and his relationship must be found. It is not enough that ground for uneasiness as to future conduct arises. ${ }^{14}$

Bushnell was known to have independently approached Blyth's customers. The board of Blyth Chemicals indicated that they, perhaps not unreasonably, had lost confidence in Bushnell given this behaviour. Nevertheless, according to the High Court Bushnell's conduct did not breach the obligation not to compete against his employer, begging the question as to what level of misconduct is required to meet the threshold.

In Blyth Chemicals the High Court used the general descriptors 'incompatible', 'employment', 'competition' and 'conflict' to illustrate when the obligation not to compete is breached. The question is, for example, whether an employee netballer playing in a mid-week 'rebel' tournament is in 'competition' or 'conflict' with the player's primary employer club?

\footnotetext{
${ }^{10}$ Hivac Ltd v Park Royal Scientific Instruments Ltd [1946] Ch 169, 174.

${ }^{11}$ Woods $v$ WM Car Services (Peterborough) Ltd [1981] ICR 666, 670.

${ }^{12}$ Including the endorsement of goods and services for reward.

${ }^{13}$ Blyth Chemicals v Bushnell (1933) 49 CLR 61.

${ }^{14}$ Blyth Chemicals v Bushnell (1933) 49 CLR 61, 81-2.
} 
Unfortunately, the above descriptors do not reveal the scope of the obligation and merely restate the obligation in different words. Much will depend on the facts; if the tournament is held in a different state to the primary employer, arguably not. If televised, perhaps so.

\section{A mutuality of obligations}

The employee's obligation of fidelity is concomitant with the employer's duty of fidelity to the employee, described in Auckland Shop Employees Union $v$ Woolworths, 'a corollary to the employee's duty of fidelity'. ${ }^{15}$ The rationale of the duty was expressed in Malik $v$ Bank of Credit and Commerce International as a means of securing 'a balance ... between the employer's interest in managing his business as he sees fit and the employee's interest in not being unfairly and improperly exploited' ${ }^{\prime}{ }^{16}$

The obligation of employer fidelity has been described as importing 'the requirements of reasonableness and the protection of reasonable expectations' where the primary emphasis is 'upon the maintenance of the personal relationship rather than a commercial contract'. ${ }^{17}$

In Woods $v$ WM Car Services (Peterborough) ${ }^{18}$ the Court emphasised that a duty of fidelity rests upon the employer: 'In our view it is clearly established that there is implied in a contract of employment a term that the employers will not, without reasonable and proper cause, conduct themselves in a manner calculated or likely to destroy or seriously damage the relationship of trust and confidence between employer and employee.'

However, the normative standard of 'trust and confidence' expected in Woods and found in most areas of employment is absent from the employment relationship of sporting organisations and their athletes. In consequence, where a sporting contract permits the employer to derogate from the normative standard of fidelity, the player may also derogate. In short the 'balance' of fidelity spoken of in Malik is different.

Capital Aircraft Services $v$ Brolin, ${ }^{19}$ although a restraint of trade case concerning a contractor, shows how a change in employment circumstances could translate into an adjusted obligation of fidelity. Brolin took work on a part-time basis with Capital to service and maintain aircraft. In defiance of a contractual term to solely work for Capital Aircraft, Brolin took work with a competitor of Capital..$^{20}$ The Court of Appeal approved the comments of Connolly J at trial:

It seems to me that all the arguments in favour of exclusive dealing clauses within employment contracts ... are based on the employee's duty of fidelity during the life of the

\footnotetext{
${ }^{15}$ Auckland Shop Employees Union v Woolworths [1985] 2 NZLR 372, 376.

${ }^{16}$ Malik v Bank of Credit and Commerce International SA (in liquidation) [1998] AC 20, 46. (Malik)

${ }^{17}$ Macken, O'Grady, Sappideen, Warburton, Law of Employment (Law Book Co, Sydney, 2002) 114.

18 Woods v WM Car Services (Peterborough) Ltd [1981] ICR 666, 670 (Woods).

${ }^{19}$ Capital Aircraft Services Ltd v Brolin [2007] ACTCA 8.

${ }^{20}$ Brolin had full-time employment with National Jet Systems to the knowledge of Capital Aircraft, who took objection to Brolin taking further casual work with Vee H Aviation.
} 
employment. But this is of course a two way street, the employee, in return for this fidelity, enjoys all the consequences of the employment relationship. ${ }^{21}$

His Honour went on to list factors inimical to the Brolin contract:

The present agreement is expressly a contract for services, and excludes the defendant from workers compensation and insurance. There is no obligation to supply any work or any defined quantum of work. ${ }^{22}$

The point is this: where an employer in hiring an employee on a part-time basis is able to avoid the usual obligations such as 'workers compensation and insurance', the 'duty of fidelity and the corresponding tendency of the common law courts to permit a degree of exclusive dealing within the life of the employment, should not be extended to an arrangement where the contractor has no defined or specified amount of work to be provided by the principal'.$^{23}$

According to Connolly J, the employer could not expect the standard of fidelity of a parttime contractor to be that of a full-time employee. By analogy, where an employer sporting organisation can avoid broadly-recognised employment obligations or, more accurately to sport, where the obligation is merely different, it is reasonable that the athlete's expected standard of fidelity should also adjust accordingly.

The facts applicable to fidelity in sports employment are sufficiently unique as to justify a 'sport specific' approach. Where, for example, the employer, perhaps on a whim, 'trades' an employee athlete for another of perceived greater talent, one may question the depth of obligation the player can concomitantly be thought to owe to the employer. The limited length of most sports careers and the possibility of injury, events which regularly result in an athlete's services being abruptly discarded, are also germane to the scope of fidelity that can be expected of athletes.

\section{Athlete dismissal and the employee's mutual obligation of fidelity}

Fidelity imposes on an employer a number of diverse obligations, none more fundamental than the employee's entitlement of ongoing employment in the absence of a dismissible wrong. Unlike terms commonly governing termination of employment, many sporting contracts expressly grant to the employer the capacity to terminate an athlete's contract for reasons unspecified and unrelated to work performance and, as argued below, for reasons based primarily on the self-serving motives of the employer. For example, Section 9.1 of the National Rugby League Playing Contract states:

\footnotetext{
${ }^{21}$ Capital Aircraft Services Ltd v Brolin [2007] ACTCA 8 at [22].

22 Ibid.

${ }^{23}$ Ibid [16].
} 
Notwithstanding any other provision of this Agreement, and whether the Club is otherwise entitled to terminate this agreement .... the Club may at anytime release a Player from his obligations under this Agreement upon providing written notice to the Player to that effect .. $.24^{24}$

Despite the seemingly innocuous word 'release', the player employee may be dismissed from his employment without a right to object. To illustrate, in 2006 South Sydney rugby league player Adam MacDougall was 'released under clause 9.1', the club stating in a press release: 'We are changing the culture of the Club and we have deemed that Adam doesn't fit into the culture we are trying to develop for the rest of the season and continuing into next year'.$^{25}$

Players may also be 'traded' to another club for reasons solely to the benefit of their present club and without reference to the effect on the athlete. Consider the relevant provision of the AFL Collective Bargaining Agreement: ${ }^{26}$

18.5 No AFL Club shall exchange any Player unless the Player has been given as much notice as possible by the AFL Club of its intention to trade without any duress being applied by the AFL Club, its employees or agents to the player and the Player genuinely consents to the trade.

Although he must 'genuinely consent' to being traded, many players would not object to an unfair transfer where it is clear the club is disinterested in their services.

Athletes also face summary transfer from their club for reasons often unrelated to their capacity to play or their enthusiasm for their work, including:

- The club decides another player is better

- The club develops a new 'team plan' not requiring the skills of the existing player

- A younger player is discovered

- An older player must stand aside for future team development

- A player may be 'traded' to secure a player in the draft

- The player enters a non-permanent form slump

\footnotetext{
${ }^{24}$ National Rugby League Playing Contract (2012) Section 9.1.

$25<$ http://www.rleague.com/db/article.php?id=25996 (at 4 November 2009). The club is obliged to pay the

'Playing Fee' but not 'Match Fees'.

${ }^{26}$ AFL Collective Bargaining Agreement 2007-2011 < http://www.afl.com.au/portals/0/afl_docs/afl _hq/policies/cba\%202007-2011\%20final.pdf.> Consider also s 18.4 'The AFL and the AFLPA recognise that Player Contracts between AFL Clubs and Players create legally binding obligations and that the parties to such agreements have legitimate expectations that the terms of such agreements will be honoured.'
} 
In some cases, such as that of MacDougall noted above, the removal of the player from the club may have nothing to do with form, but rather suitability within the mix of other players. Where poor form is a factor, mutual fidelity or club loyalty will not save a player from dismissal or transfer and, unlike many other types of employment, a club may not wait for the worker's performance to reignite.

An athlete's services may also be terminated for breaching specific (and non-specific) contractual terms, such as bringing a sport into disrepute. Section 8 of the NRL Players Contract permits the club to 'terminate this agreement with immediate effect' should the player breach obligations not to 'engage in misconduct or act in a manner contrary to or prejudicial to the best interests, image or welfare of the club, the NRL or the game during the term of employment.' Termination can also result from: 'fail to report a bribe, not play on merits, fail to obey a reasonable direction of the Club relating to training and or playing the game, fail to obey a request by a referee to leave the ground'.

Sanctions such as those above are necessary to ensure the proper operation of a sporting organisation. However, the decision of the club to terminate the player's employment, usually through the decision of a Chief Executive Officer, is often made on a subjective or personal level without necessarily referencing the player's 'wrong' against the objective standards of the wider community or against those of other players. As such, the reasons justifying dismissal are largely in the eye of the decision-maker suggesting a form of employer fidelity different from that of other fields of employment.

In addition, the power of dismissal may be exercised capriciously depending on who the offending player is, rather than according to the seriousness of the wrong. For example, in 2006 the Newcastle Knights Rugby League rookie Dane Tilse 'after an alcohol-fuelled incident involving a woman at Bathurst ... was kicked out by the club and the NRL less than 48 hours after he behaved badly.' At the same time, Penrith player Craig Gower was 'fined 30,000 and sacked as Penrith captain after groping Wayne Pearce's daughter at a charity golf day, but his career can continue unabated' ${ }^{27}$ During the period of the Tilse dismissal, Newcastle 'star' Andrew Johns was, self-admittedly, engaged in wide spread drug use and public misconduct, acts for which he was never brought to account by his employer. ${ }^{28}$

As a contractual right following a breach, an executive officer may mildly punish prominent players and harshly deal with those of lesser stature, should he or she so desire. ${ }^{29}$ This is not to say that the contractual power to summarily terminate the player's employment does not exist but rather, in respect of the present discussion, that the mutual duty of fidelity in sport

\footnotetext{
27 W Stanton, 'Tilse Refusing to Cry Foul at Gower's Star Treatment' The Sun-Herald, 8 January 2006.

${ }^{28}$ A similar argument was mounted by the Manly Rugby League Club following the four match suspension of player Brett Stewart by the NRL ostensibly for public intoxication in 2009. Stewart's suspension was compared to the non-suspension of West's Tigers player Benji Marshall following a charge of assault after an incident in a Sydney McDonalds in 2011.

${ }^{29}$ Holland $v$ Wiltshire (1954) 90 CLR 409.
} 
is not that of the wider community. In Riverwood International v McCormick Mansfield J considered the application of an express power to be:

constrained by an implied term that it would act with due regard for the purposes of the contract of employment ... so it could not act capriciously and arguably could not act unfairly ... There might also be a power which, by implication, must be exercised reasonably having regard to the nature of the contract and the entitlements which exist under it. ${ }^{30}$

In fact the exercise of a power to dismiss without reasonable cause is adverse to the generally recognised obligation of trust and confidence owed by the employer to an employee. In this respect the Industrial Tribunal in Woods $v$ WM Car Services (Peterborough) stated:

Experience in this Tribunal has shown that ... employers who wish to get rid of an employee or alter the terms of employment without becoming liable either to pay compensation for unfair dismissal or a redundancy payment have had to resort to methods of 'squeezing out' an employee. Stopping short of any major breach of the contract, such an employer attempts to make the employee's life so uncomfortable that he resigns or accepts revised terms....

In our view, an employer who persistently attempts to vary an employee's conditions of service (whether contractual or not) with a view to getting rid of the employee ... does an act in a manner calculated or likely to destroy the relationship of confidence and trust between employer and employee. Such an employer has therefore breached the implied term. Any breach of that implied term is a fundamental breach amounting to a repudiation since it necessarily goes to the root of the contract.' ${ }^{31}$

Akin to 'squeezing out' is the potential to use the 'misconduct' clause found in most sporting contracts as a means to secure the ulterior purpose of player dismissal where, on an objective or comparative assessment, dismissal is unwarranted.

Dismissal for misconduct, trading a player in the mid-term, or dismissing a player without employment related cause is an accepted or at least a common practice of many sporting organisations. Such actions evince an employment relationship very different from that commonly found in other fields of employment. Where dismissal, for example, is summarily exercised according to the arbitrary or personal views of decision-makers, it is right to question whether it can be expected that the level of fidelity applicable to the wider community is pertinent to the sporting community.

\section{Conclusion}

The old restraint of trade paradigms which excused limitations on secondary work during the currency of employment are outmoded. Part-time and flexible work conditions are now

\footnotetext{
${ }^{30}$ Riverwood International v McCormick (2000) 177 ALR 193 at [150-152].

${ }^{31}$ Woods v WM Car Services (Peterborough) Ltd [1981] ICR 666, 672.
} 
more common. This argument is made more broadly by Riley who suggests that the changing nature of the work relationship has altered the legal rights of employees:

Claims to enforce post-employment restraint covenants or duties of confidence are really assertions of rights to sterilize, or at least handicap, the employee's exploitation of his or her own human capital. In the new boundary-less workplace, the law ought not to support such claims. The same economic justifications which support flexible work practices and a weakening of the employers commitment to long term engagement of particular workers, also support the liberty of the worker to carry a full range of talents, skills, knowledge and connections into new jobs and new careers. ${ }^{32}$

Riley's comment refers specifically to post-employment restraints of trade. What is important, however, is recognition that the erosion of what might be termed 'employer loyalty' calls for a reappraisal of how far the employee athlete's obligation of fidelity can be expected to extend in the present age.

The point is not that the obligation of fidelity by clubs to players should expand, but rather that the difference should be recognised as a norm and the athletes' obligations adjusted accordingly. While much could be said of the 'vague'33 notion of fidelity as it applies to sport, there is no doubt that the obligation is one mutually owed. In this sense the standard of fidelity expected of the athlete can be no higher than that of the employer. Suffice to say that the nature of sport employment requires the obligation of fidelity to be considered against the unique circumstances of the sport in question.

\footnotetext{
32 Riley J, "Who Owns Human Capital? A Critical Appraisal of Legal Techniques for Capturing the Value of Work", (2005) 18 Australian Journal of Labour Law 1 at 2.

${ }^{33}$ Hivac Ltd v Park Royal Scientific Instruments Ltd [1946] Ch 169 at 173.
} 